\title{
Morphological, Physiological and Nutritional Effects of Irrigation Frequency on Macaúba Palm Seedlings
}

\author{
C. P. Hernández ${ }^{1}$, Hewlley Acioli Imbuzeiro ${ }^{1}$, Leonardo Duarte Pimentel ${ }^{2}$, Paulo José Hamakawa ${ }^{1}$ \\ \& Arend-Jan Both ${ }^{3}$ \\ ${ }^{1}$ Department of Agricultural Engineering, Federal University of Viçosa, Viçosa, MG, Brazil \\ ${ }^{2}$ Department of Plant Science, Federal University of Viçosa, Viçosa, MG, Brazil \\ ${ }^{3}$ Department of Environmental Science, Rutgers University, New Brunswick, NJ, USA \\ Correspondence: C. P. Hernández, Department of Agricultural Engineering, Federal University of Viçosa, Viçosa, \\ MG, Brazil. E-mail: cindyhdez@hotmail.com
}

Received: December 26, 2017

Accepted: February 22, $2018 \quad$ Online Published: March 15, 2018

doi:10.5539/jas.v10n4p24

URL: https://doi.org/10.5539/jas.v10n4p24

\begin{abstract}
The commercial nurseries of macaúba palm (Acrocomia aculeata) have experienced excessive seedling mortality, which is possibly due to the lack of information about the proper growing practices. The goal of this study was to investigate the response of macaúba seedlings to water stress using different irrigation frequencies during the early seedling stage. The experiment was carried out in a macaúba palm nursery located in João Pinheiro, Minas Gerais, Brazil. The treatments started 30 days after sowing. At 90 days after sowing, the morphological (number of leaves, stem diameter, shoot length, root weight and the fresh and dry matter content of leaves, stem and roots), physiological (allocation of photosynthates) and chemical (nutrient content in the shoot) characteristics were evaluated. The results indicated that shoot height and stem diameter became smaller as the frequency of irrigation was reduced. However, the accumulation of fresh biomass in leaves and stems, and the leaf and root dry biomass became higher under the same condition. When water stress was induced in younger seedlings, the allocation of photosynthates occured more proportionally across all organs of the plants. The highest accumulation of $\mathrm{K}, \mathrm{S}$ and $\mathrm{Fe}$ in the shoot were observed in plants that were exposed to water stress. $\mathrm{N}$ accumulation was higher in the aerial part of the seedlings as the irrigation frequency increased. However, the opposite behavior was observed for $\mathrm{P}$, which accumulation was lowest in the control treatments.
\end{abstract}

Keywords: Acrocomia aculeata, Brazil, nursery production, nutrient content

\section{Introduction}

The macaúba palm, Acrocomia aculeata, Jacq. Lodd. Ex Mart., is a perennial palm native to Amazonian regions. The species grow in the savannas and open forests of tropical America, which are distributed from Central America to southern South America. It is probably found naturally in almost all the Brazilian territory, especially across the Southeast and Central West regions (Pimentel et al., 2015; dos Reis, Pinto, da Assunção, \& da Silva, 2017). This species has an annual flowering season in Brazil from September through February and with peak flowering from November through December (Berton, 2013), which coincides with the season of highest rainfall in the areas in which it grows (Colombo, Berton, Diaz, \& Ferrari, 2017). Fruiting occurs throughout the year after the fourth year in the field and generally the fruits are ripe 12 to 13 months after fertilization (Giraldo Montoya, Motoike, Kuki, De Oliveira, \& Gomes Honorio, 2015).

Due to the oleaginous properties of the fruits (Evaristo et al., 2016), macaúba palm is considered one of the most promising crop species as a source of oil for the biofuel industry (biodiesel, bio-kerosene and others), cosmetics and food. Currently, two types of oils are produced; one of them is extracted from the endosperm, which represents approximately $15 \%$ of the total oil of the plant. This oil is used in various products such as animal food cakes, food items for human consumption, cosmetics, etc., (Azevedo Filho, Colombo, \& Berton, 2012; Santos et al., 2017). Additional oil is extracted from the mesocarp, which has good characteristics for industrial processing and can be used for the production of biofuels (Martins, 2011; Motoike et al., 2013).

The agricultural yield of macaúba palm varies between 4,000 and 6,000 liters of oil per hectare, which is short of only the oil palm (Elaeis guineensis, Jacq.) that yields up to 8,000 liters of oil per hectare. The macaúba tree can 
be used in its entirety; from the leaves that are used as animal feed and for the manufacturing of fishing lines, to the fruits (kernels) that are used for oil extraction (Hiane, Baldasso, Marangoni, \& Macedo, 2006). The production of fresh fruits consists of approximately 4 bunches per tree (Carvalho, Souza, \& Machado, 2011) corresponding to approximately $80 \mathrm{~kg}$ of fruits/tree/year (Azevedo Filho, Colombo, \& Berton, 2012). Each bunch produces approximately $6.3 \mathrm{~kg}$ of pulp and $1.4 \mathrm{~kg}$ of endosperm, which are used in products made for human consumption with high energy nutritional value due to the presence of bioactive compounds such as phenols and $\beta$-carotene (Siqueira, 2012) and for the extraction of oil (Sanjinez-Argandoña \& Chuba, 2011).

The crop has been classified as economically relevant, similar to the agricultural importance of sugarcane in Brazil, however, in commercial nurseries an unacceptable high seedling mortality rate has been observed. Specifically, it was noted that seedlings frequently suffered from water stress that resulted in reduced survival rates. The current study evaluated various irrigation frequencies during seedling production because it was hypothesized that a gradual reduction in the number of irrigations would allow the plants to adjust their physiological and morphological characteristics, resulting in better adaptability to the water deficit conditions in the field after transplant. The seedling production stage is critical in order to obtain uniform plant material. During this growth stage, the type of substrate, container volume, irrigation, fertilization and the growing conditions are paramount for obtaining healthy and vigorous seedlings (Martins, 2011). Therefore, the objective of this study was to evaluate the morphological, physiological and nutritional characteristics of macaúba palm seedlings grown under various irrigation frequencies during the early seedling production stage.

\section{Method}

The experiments were conducted from February through May, 2016 at the commercial nursery of Acrotech Sementes and Reforestation, located geographically at latitude $17^{\circ} 42^{\prime} 34^{\prime \prime} \mathrm{S}$, longitude $46^{\circ} 15^{\prime} 46^{\prime \prime} \mathrm{W}$, at an altitude of $605 \mathrm{~m}$ and located in the municipality of João Pinheiro in the state of Minas Gerais (Figure 1). According to the classification of Kopper, the climate of the region is mostly tropical (Aw), with a rainy season between the months of October and March. The average annual rainfall is $1,400 \mathrm{~mm}$ and the temperature ranges between a maximum of $28.8^{\circ} \mathrm{C}$ and a minimum of $16.5^{\circ} \mathrm{C}$, with an average relative humidity of $41 \%$.

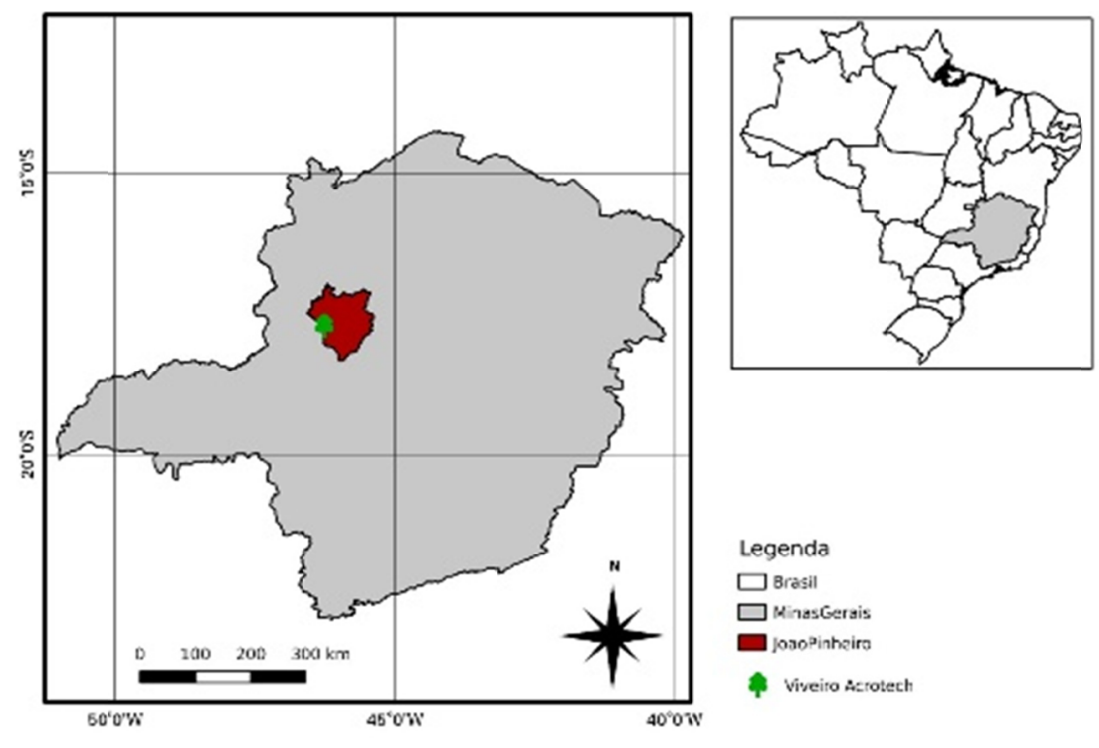

Figure 1. Map showing the location of the experiments: the municipality of João Pinheiro, northwest in the state of Minas Gerais, in the southeast of Brazil

\subsection{Cultivar and Structure}

The cultivar used was Acrocomia aculeata, (Jacq.) Lood. Ex Mart. The following sequential processes were carried out during the experiment: filling of the growing containers (tubes) with the growing media (substrate); placing the tubes in growing trays; sowing the pre-germinated seeds in the tubes and transporting the trays to the greenhouse where they remained for 90 days. Additional details cannot be provided as they are considered proprietary information by the commercial nursery where the experiment was conducted. 
The greenhouse structure had a total growing area of $1,200 \mathrm{~m}^{2}$, with a width of $20 \mathrm{~m}$ (and a post spacing of $10 \mathrm{~m}$ ) and its orientation was of East-West. The length of the greenhouse was $60 \mathrm{~m}$ and gutter height was $4 \mathrm{~m}$. The groud surface was covered with raffia and the greenhouse structure consisted of galvanized steel supports. The greenhouse structure was covered with low density polyethylene (LDPE) plastic film with a thickness of $152 \mu \mathrm{m}$. The greenhouse was equipped with an internal movable shade curtain (with 50\% light transmission).

\subsection{Treatments and Sampling Procedures}

During the first part of the experiment (from sowing to Day 30), the seedlings were grown under consitent conditions, including the irrigation (amount and frequency). When the seedlings reached a height of approximately $5 \mathrm{~cm}$ (after 30 days), the irrigation frequency for the plants in treatment 2 (T2) was changed from twice to once per day. Seedlings in treatment 1 (T1) were watered with a different irrigation frequency starting 45 days after sowing. Seedlings in the control treatment (T0) were irrigated twice per day throughout the experiment (Figure 2). For all treatments, the total amount of water applied during the experiment was $4 \mathrm{~mm}$ per day. A total of 160 seedlings, 10 plants per plot and 4 replicates per treatment were used.

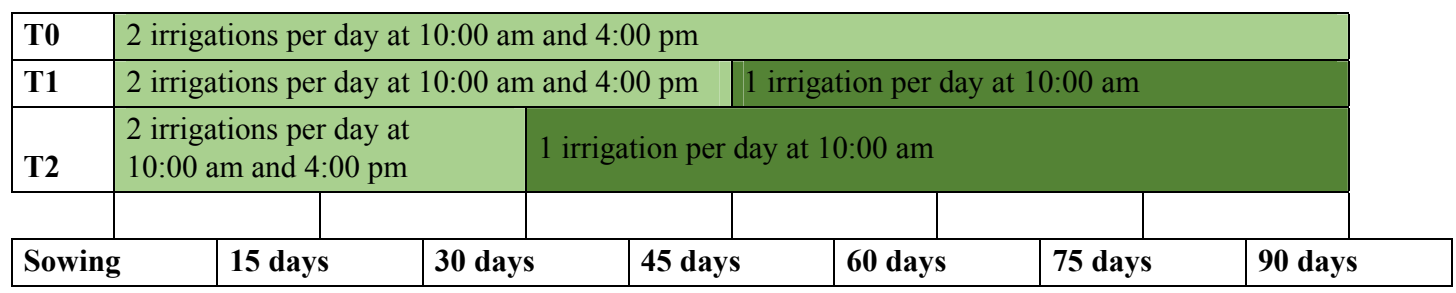

Figure 2. Representation of the three irrigation treatments used during the seedling production of Acrocomia aculeata, Jacq. Lodd. Ex Mart

Note. T0 (Control Treatment): two irrigations per day, for 90 days, at 10:00 and 16:00 h; T1: one irrigation per day starting at 45 days after sowing, at 10:00 h; T2: one irrigation per day starting at 30 days after sowing, at 10:00 $\mathrm{h}$ (Figure 2). For all treatments, the total amount of water applied during the experiment was $4 \mathrm{~mm}$ per day.

At the end of the experiment (Day 90), a sample of 8 plants per treatment ( 2 plants per block) was used for destructive analysis and evaluation of the number of leaves, shoot height, stem diameter, root length, leaf area and dry matter, and fresh weights of the leaves, roots and stem. Each seedling was separated into leaves, stem and root and then weighed for the determination of fresh biomass.

The samples were then placed in paper bags and put in a drying oven with forced air circulation at a temperature of $65{ }^{\circ} \mathrm{C}$ until constant weight was obtained. At the end of this time, the samples were weighed to determine the dry weight of the leaves, stem and roots. The dry and ground samples of leaves, stem and roots were submitted to nitric-perchloric digestion to determine the macronutrient $(\mathrm{P}, \mathrm{K}, \mathrm{Ca}, \mathrm{Mg}$ and $\mathrm{S})$ and micronutrient $(\mathrm{Mn}, \mathrm{Cu}, \mathrm{Fe}$ and $\mathrm{Zn}$ ) content. The $\mathrm{P}$ content was determined by the colorimetry method, $\mathrm{K}$ by flame photometry, $\mathrm{Ca}, \mathrm{Mg}, \mathrm{Fe}$, $\mathrm{Mn}, \mathrm{Cu}$ and $\mathrm{Zn}$ by atomic absorption spectrometry, and $\mathrm{S}$ by turbidimetry. Nitrogen was determined using the Kjeldahl method after sulfur digestion. The macro and micronutrient contents were expressed in units of $\mathrm{g} \mathrm{kg}^{-1}$ and $\mathrm{mg} \mathrm{kg}^{-1}$, respectively.

\subsection{Environmental Conditions Inside of the Greenhouse}

\subsubsection{Solar Radiation}

The accumulated solar radiation inside the greenhouse was estimated based on the hourly information obtained from a meteorological station located in the municipality of João Pinheiro, which belongs to INMET (Instituto Nacional de Meteorologia). The INMET uses an automatic meteorological station (EMA), brand Vaisala; model MAWS 301. The Sampling for solar radiation happens every 5 seconds. The "snapshot" value used in weather reports is the average of one minute (of 12 sample values).

The amount of light blocked by the plastic film that covered the greenhouse and the light reduction due to the shade cloth that was installed inside the greenhouse was subtracted from the global average monthly solar radiation. These quantities were estimated to be $20 \%$ and $50 \%$ of the global solar radiation, respectly. The results of the indoor global radiation can be calculated using Equation 1: 


$$
R g_{e}=R g-(0.2 \times R g+0.5 \times R g)=R g-0.7 R g
$$

Where,

$R g_{e}=$ Global solar radiation inside the greenhouse $\left(\mathrm{mol} \mathrm{m}^{-2} \mathrm{~d}^{-1}\right) ; R g=$ Outside global solar radiation incident on the greenhouse cover $\left(\mathrm{mol} \mathrm{m}^{-2} \mathrm{~d}^{-1}\right)$.

It should be noted that these values correspond to 3 months of observation, a period during which there was little rainfall and low cloudiness (Figure 3).

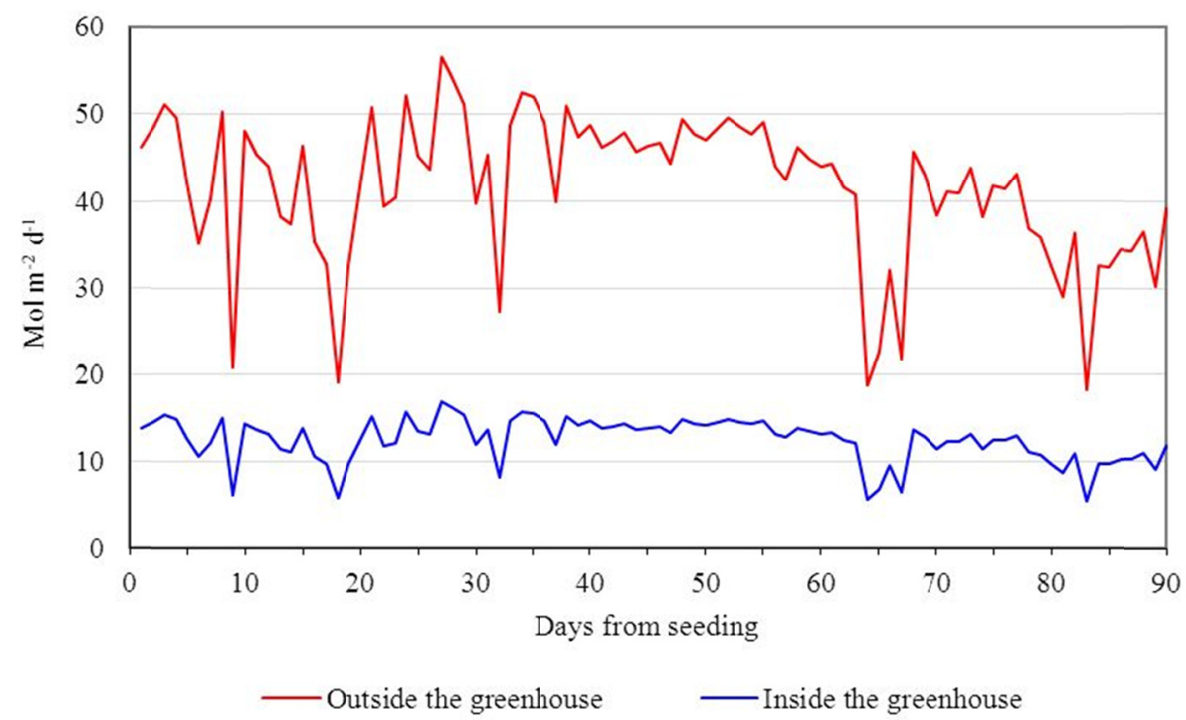

Figure 3. Comparison between the solar radiation outside and inside to the greenhouse when the attenuation of the plastic and of the shade material used inside the house of vegetation is subtracted

The amounts of shortwave and longwave, and direct and diffuse radiation were not measured during the experiment. As a result of the greenhouse film and the shade curtain, the amount of diffuse radiation is expected to be larger inside the greenhouse compared to outside. Because diffuse radiation is multi-directional, it can increase crop photosynthesis, especially when crops with taller canopies are grown.

\subsubsection{Temperature}

The temperature inside the greenhouse was measured using an automatic psychrometer (Incoterm, model 7665.02.0.0) that recorded the minimum, maximum and average temperature using dry and wet bulb thermometers. The calibration process consisted of comparing the instrument to an already calibrated standard. These tests are done in the laboratory, recognized by a Brazilian federal autarchy National Institute of Metrology, Standardization and Industrial Quality, and its acronym in Portuguese INMETRO. The average internal greenhouse temperature was $39.2{ }^{\circ} \mathrm{C}$ and the average outside temperature was $23.1{ }^{\circ} \mathrm{C}$ (Figure 4).

Solar radiation has a direct effect on the temperature inside and outside the greenhouse, because when solar radiation passes through the plastic glazing material the plants absorb short wavelength radiation and emit long wavelength radiation, also known as heat or infrared radiation. These infrared rays can not pass through the greenhouse glazing material and are therefore trapped inside the greenhouse, thus increasing the internal temperature. 


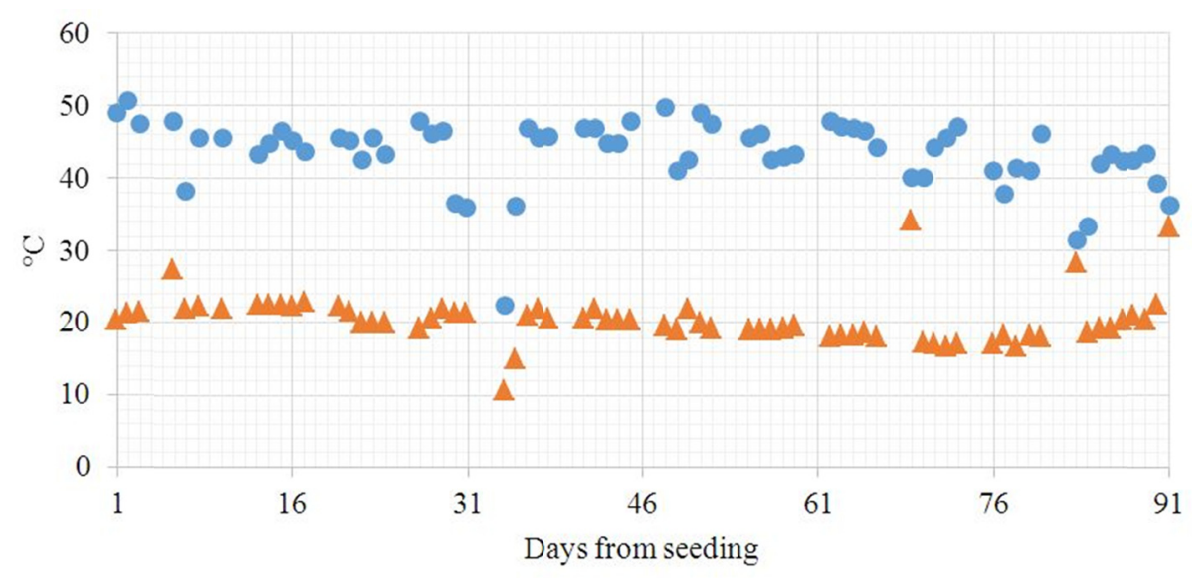

- Maximum $\quad$ Minimum

Figure 4. Daily maximum and minimum temperatures recorded inside the greenhouse during the experimental period

The difference between the daily maximum and minimum temperatures inside the greenhouse is greater than outside, and ranged between 23.2 and $1.2{ }^{\circ} \mathrm{C}$. This relatively large range can be explained by the fact that the longwave radiation impacted the daily maximum temperature more than the daily minimum temperature.

\subsubsection{Relative Humidity}

The values of relative humidity inside the greenhouse were obtained analytically by using the dry and wet bulb temperature data recorded by the psychrometer. The values obtained were higher outside the greenhouse than inside the greenhouse (Figure 5).

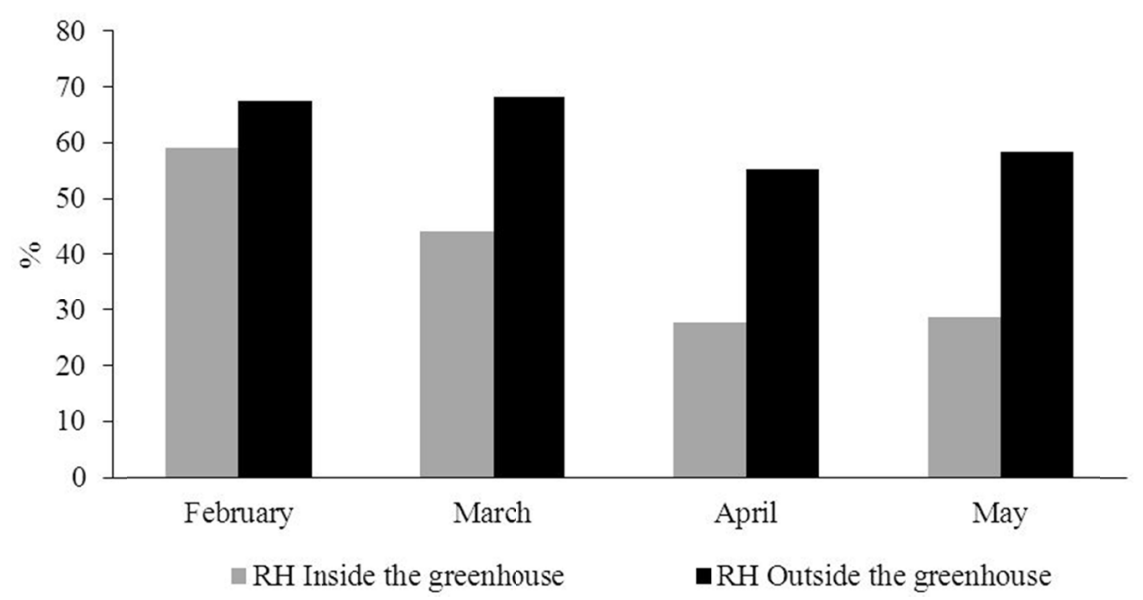

Figure 5. Average inside and outside realtive humidity during the experimental period

The lower relative humidity inside the greenhouse is related to the higher temperature reached inside. Both variables are inversely proportional, so the higher inside temperature during the day causes the inside relative humidity to decrease. Knowing that the relative humidity is defined as the ratio of the water vapor pressure to the saturated water vapor pressure, when there is a condition of rising air temperature, the saturated water vapor pressure also automatically increases, causing the relative humidity to decrease inside the greenhouse.

\subsection{Statistical Design}

For each treatment, four blocks were used in a completely randomized block design. The software ASISTAT V 7.7 beta was used for the analyses.

Analysis of Variance was used to evaluate the results (using $\mathrm{p} \leq 0.05$ ). In order to verify if there was a significant 
difference between the populations of the treatments, the F-test was performed using a probability level of 5 and $1 \%$ for the ratio of the highest and the lowest variance (Fisher, 1935) (Equation 2):

$$
F=\frac{S_{A}^{2}}{S_{B}^{2}}
$$

Where,

$S_{A}^{2}=$ variance of sample $1 ; S_{B}^{2}=$ variance of sample 2 .

Next, in order to evaluate the magnitude of the differences between the means, the Tukey $(p \leq 0.05)$ multiple comparisons test was applied (Tukey, 1953), which allows for an evaluation of the contrast between two means of treatments. This test is based on the Significant Minimum Difference (DMS), using the following equation (Equation 3):

$$
\Delta=q \sqrt{\frac{Q M R e s}{r}}
$$

Where,

$q$ is the total amplitude value; QMRes is the mean square of the residue; $r$ is the number of repetitions.

\section{Results}

\subsection{Morphological Features}

The shoot height showed a significant difference (ANOVA: $F=16.0457 ; \mathrm{p}<0.01$ ) among the treatments. Values of $27.80,21.53,19.58 \mathrm{~cm}$ were recorded for T0, T1 and T2, respectively, representing a reduction of $27 \%$ and $30 \%$ relative to the control treatment, (Figure 6A). No significant differences were observed in the root length among the treatments (ANOVA: $\mathrm{F}=0.1461 ; \mathrm{p}>0.05$ ).

The stem diameter of the seedlings (ANOVA: $F=49.96 ; \mathrm{p}<0.01$ ) showed significant differences among treatments (Figure 6B). Treatment T1 resulted in a mean of $4.04 \mathrm{~mm}$ and T2 in a mean of $3.73 \mathrm{~mm}$, both smaller than the stem diameter recorded for the control treatment which resulted in a value of $5.46 \mathrm{~mm}$, representing a decrease of $26 \%$ and $32 \%$, respectively.

The number of leaves recorded for the different treatments did not result in a statistically significant difference between the treatments (ANOVA: $F=0.6364 ; \mathrm{p}>0.05$ ) (Figure 6C).

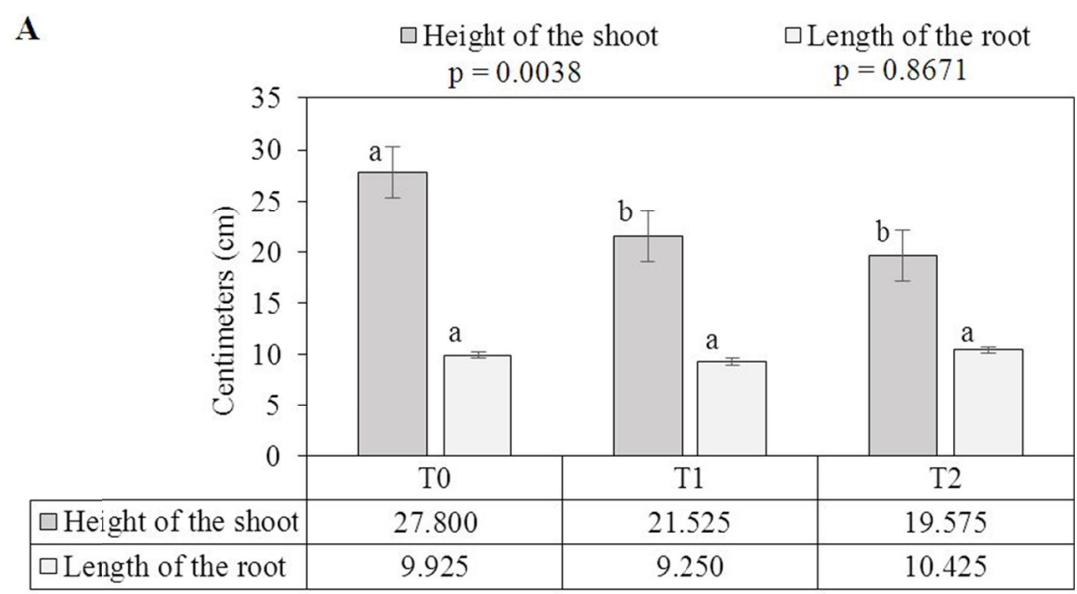



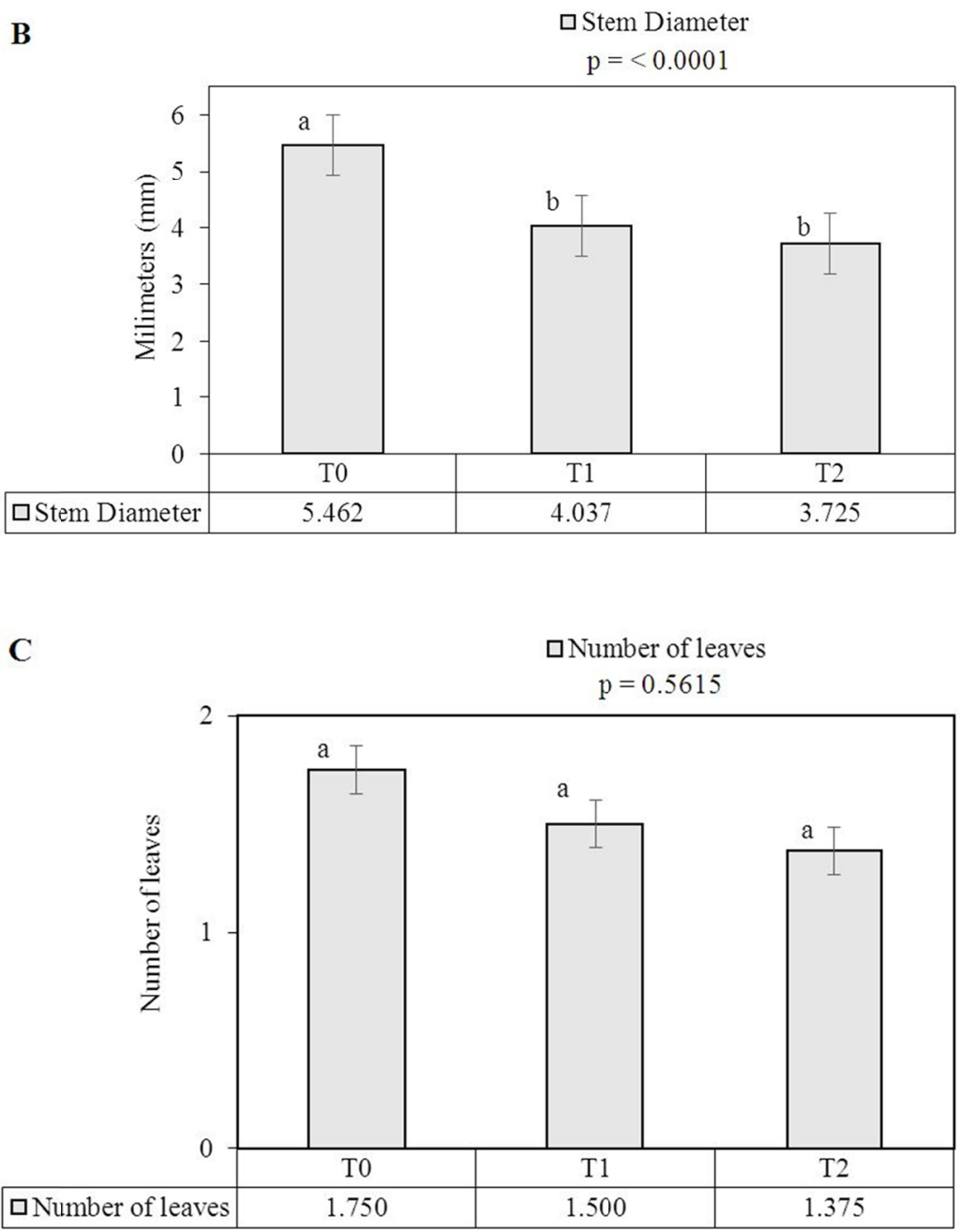

Figure 6. Comparison of the means of the morphological variables of Acrocomia aculeata, Jacq. Lodd. ex Mart., obtained by the Tukey test

Note. A. Height of the aerial part (shoot) and root length; B. Stem diameter and C. Number of leaves, for 3 treatments: T0: Two irrigations per day, for 90 days; T1: One irrigation per day, starting 45 days after seeding; T2: One irrigation per day, starting 30 days after seeding. Equal letters indicate a lack of significant difference based on the Tukey test.

\subsection{Analysis of Biomass Production}

The irrigation frequency affected the macaub seedlings in terms of biomass production. The biomass production differed when comparing the treatments 1 and 2 to the control. The fresh leaf biomass (BFF) showed a significant difference among the treatments (ANOVA: $F=13.0246 ; \mathrm{p}<0.01$ ), resulting in lower BFF values for the treatments compared to the control, (Figure 7A). The BFF for the treatments compared to the control was $46 \%$ for $\mathrm{T} 1$ and $65 \%$ for $\mathrm{T} 2$, respectively. Regarding the fresh stem biomass (BFE) (ANOVA: $\mathrm{F}=12.4703 ; \mathrm{p}<$ 0.01 ), the $\mathrm{T} 1$ and $\mathrm{T} 2$ treatments showed a significant difference relative to the control treatment at 42 and $60 \%$, respectively. However, the fresh root biomass (BFR) (ANOVA: $F=1.0078 ; p>0.05$ ) was not affected by the variation in irrigation frequency.

The accumulation of dry leaf biomass (BSF) in macaúba seedlings was affected by the irrigation frequency during the early seedling stage (ANOVA: $F=13.3450 ; p<0.01$ ). The Tukey test indicated that the mean BSF for the treatment that received the highest amount of water (control) during the 90 days was higher when compared to the average BSF for the other treatments: 45 and $65 \%$ of the control treatment for $\mathrm{T} 1$ and $\mathrm{T} 2$, respectively, (Figure 7B). 
Similarly, the dry root biomass (BSR) measurements varied between the two treatments, with T1 45\% and T2 55\% lower compared to the control. On the other hand, the dry stem biomass (BSE) (ANOVA: $F=2.976 ; p>0.05)$ was not affected by the different irrigation strategies.

A

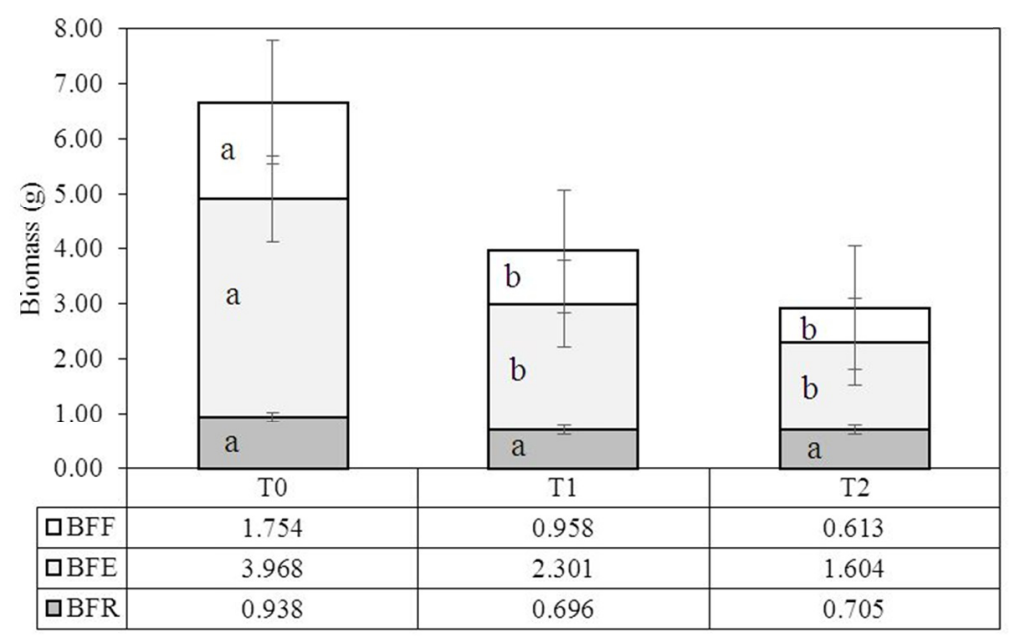

B

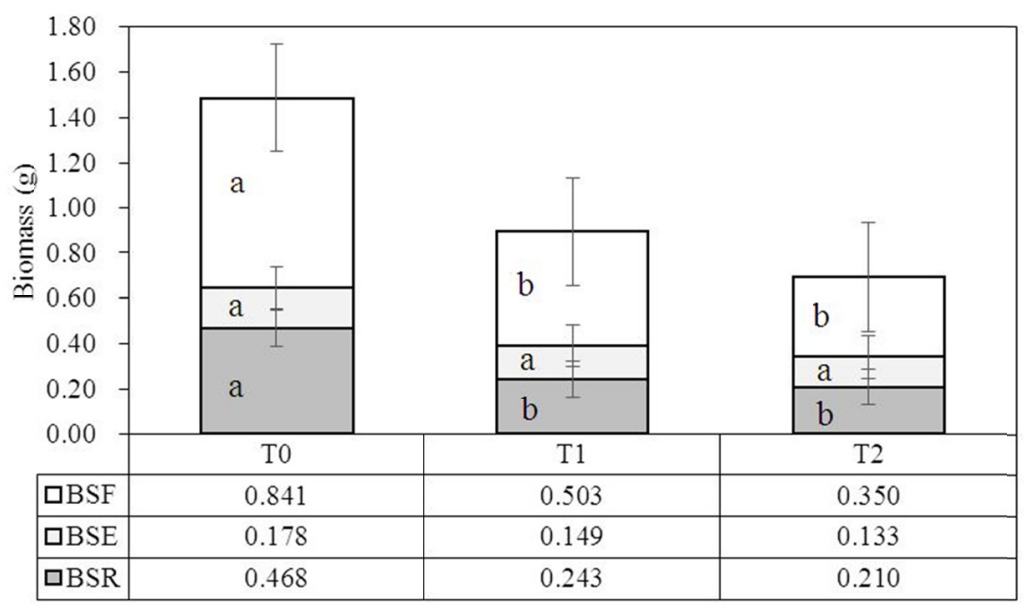

Figure 7. Biomass production: A. Fresh and B. Dry biomass of leaves, stem and roots for seedlings of Acrocomia aculeata, Jacq. Lodd. ex Mart.

Note. T0 (control): Two irrigations per day, for 90 days; T1: One irrigation per day, starting at 45 days after seeding; T2: One irrigation per day, starting at 30 days after seeding. BFF: Fresh leaf biomass; BFE: Fresh stem biomass; BFR: Fresh root biomass; BSF: Dry leaf biomass; BSE: Dry stem biomass; BSR: Dry root biomass.

\subsection{Foliar Analysis}

The N, K, Ca, Mg and S content did not show statistically significant differences (ANOVA: $\mathrm{F}=0.2834,2.8936$, $0.3722,0.7524,1.6871$, respectively, $\mathrm{p}>0.05$ ) (Figure $8 \mathrm{~A}$ ). The $\mathrm{P}$ content showed a statistically significant difference between the treatments (ANOVA: $\mathrm{F}=10.0958 ; \mathrm{p}<0.01$ ). The concentration of $\mathrm{P}$ in the leaves of seedlings that were submitted to water stress was higher for T1 and T2 (at 5.66 and $5.52 \mathrm{~g} \mathrm{~kg}^{-1}$, respectively) compared to the control treatment (at $3.47 \mathrm{~g} \mathrm{~kg}^{-1}$ ).

The content of micronutrients $\mathrm{Mn}, \mathrm{Cu}$ and $\mathrm{Zn}$ did not result in statistically significant differences (ANOVA: $\mathrm{F}=$ $1.6871,0.4904,0.7509,1.1886$, respectively, $\mathrm{p}>0.05)$. The Fe content was significantly different between on the one hand the control and treatment $\mathrm{T} 1$, and on the other hand treatment T2 (ANOVA: $\mathrm{F}=10.0958 ; \mathrm{p}<0.01$ ), (Figure 8B). 
Seedlings that were submitted to higher levels of water stress displayed a higher Fe content. Specifically, T2 showed an increase of $122 \%$ relative to the control. On the other hand, T1 resulted in a Fe content of $84.15 \mathrm{mg}$ $\mathrm{kg}^{-1}$, an increase of $16 \%$ realative to the control.

During the first 90 days after seeding, water supply is essential since cell elongation depends on water uptake by the plants. This may explain the observed linear relationship between the reduction in the frequency of irrigation and the lower growth of the aerial seedling parts (Figure 6A).
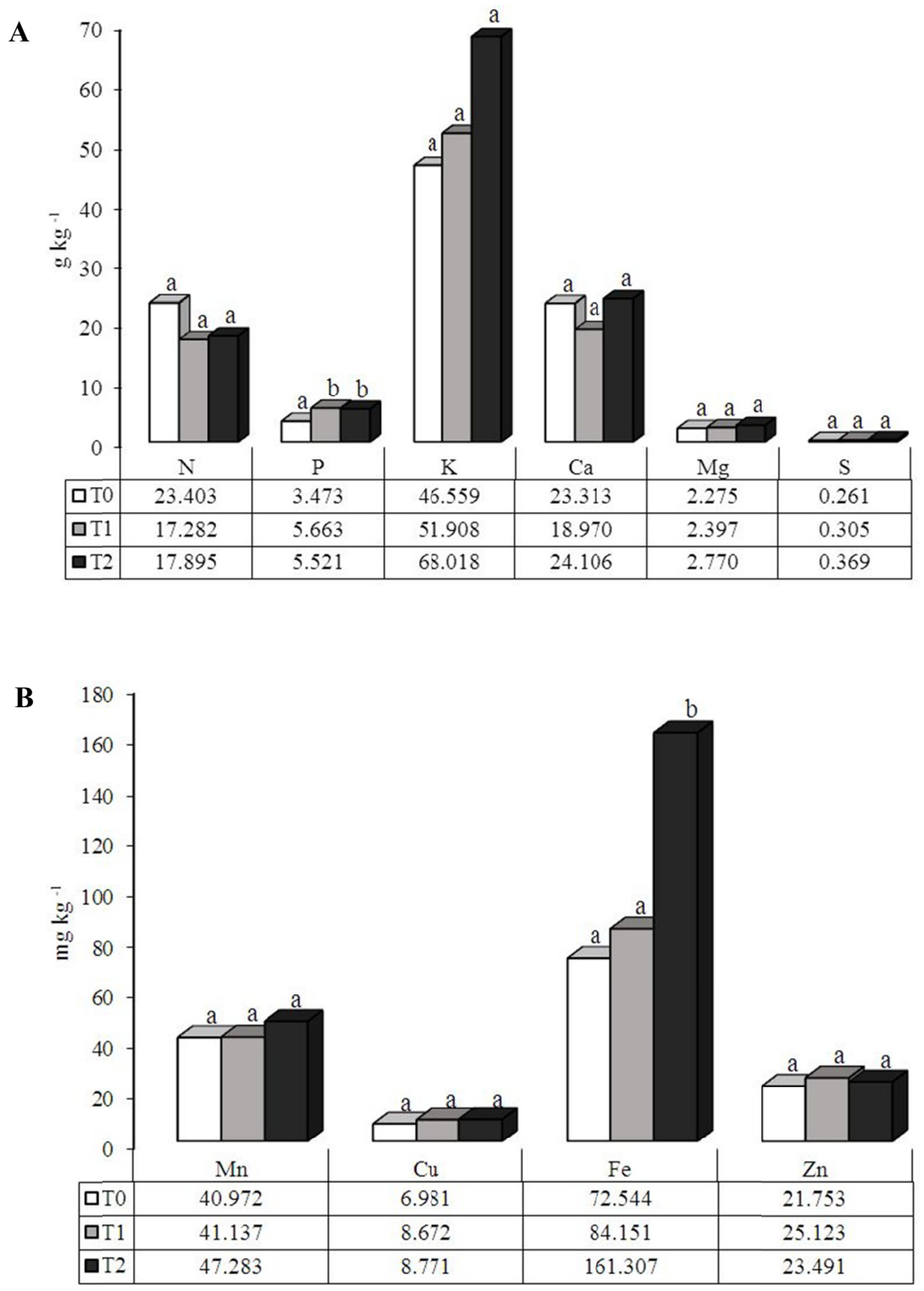

Figure 8. Levels of A. Macronutrients, and B. Micronutrients in seedling shoot tissue of Acrocomia aculeata, Jacq. Lodd. ex Mart.

Note. T0: Two irrigations per day, for 90 days; T1: One irrigation per day, starting at 45 days after seeding; T2: One irrigation per day, starting at 30 days after seeding.

\section{Discussion}

The physiological responses of the seedlings exposed to water stress became more evident when the partition of photosynthates was evaluated, indicating the utilization of photosynthates during the water stress treatments. No statistically significant difference was observed regarding photosynthate accumulation in the leaves and roots. 
However, there was a statistically significant difference among the treatments with respect to the photosynthate accumulation in the stem: the photosynthate accumulation in the stem was smaller in the control treatment (Figure 9). These results suggest that the water-stressed seedlings have a higher water use efficiency and accumulate more photosynthates in their stems. These results are similar to those reported by Barleto (2011), who showed that water-stressed macaúba seedlings had better stomatal control and reduced leaf transpiration under conditions of water stress, which consequently increased the water use efficiency. This might explain the increase in photosynthate accumulation in the stems of water-stressed seedlings. During T2, all plant parts accumulated dry matter throughout the growth cycle of the seedlings, indicating that macaúba seedlings were able to grow adequately under conditions of water stress. This ability indicates a potentially higher survival rate during subsequent field production.

In plants under water stress, the concentration of abscisic acid (ABA) is known to increase, causing stomatal closure and decreased dry matter accumulation in the aerial plant parts. This would cause the plant to allocate photosynthates for root production (Sharp, 2002). This suggests that distributed irrigation could positively affect carbon accumulation in leaves when compared to a single irrigation (the total amounts being equal). Similar, it is possible that the more uniform availability of water would improve carbon fixation in the seedlings, resulting in a greater accumulation of biomass.

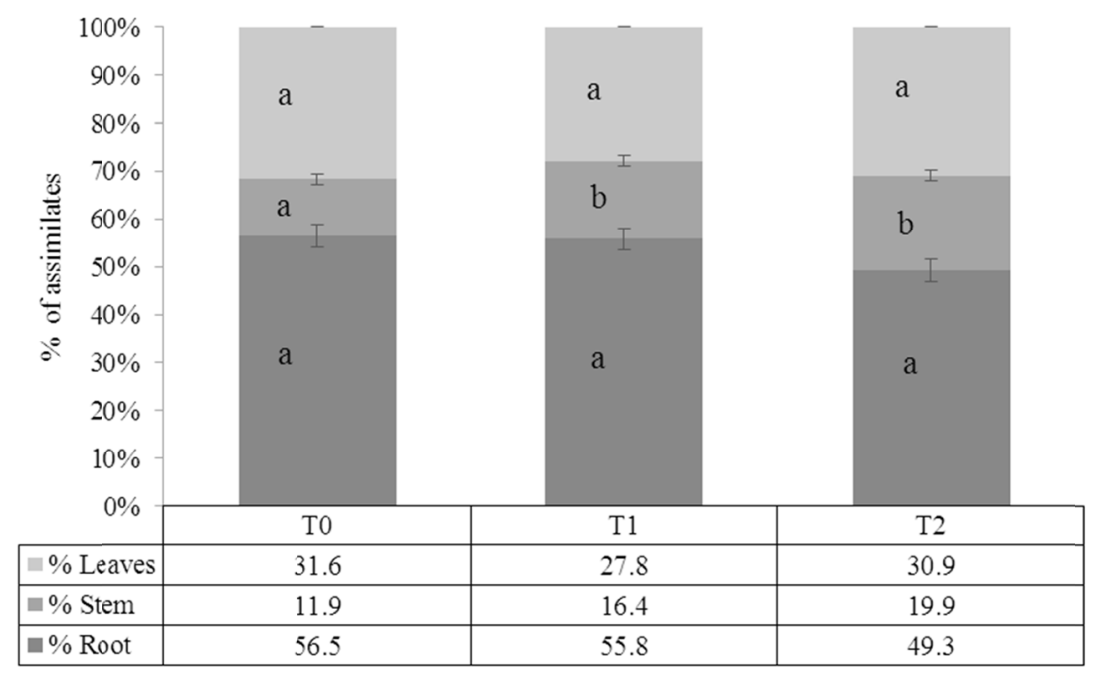

Figure 9. Partitioning of photosynthates into leaves, stem and roots of Acrocomia aculeata, Jacq. Lodd. ex Mart.

Note. T0: Two irrigations per day, for 90 days; T1: One irrigation per day, starting at 45 days after seeding; T2: One irrigation per day, starting at 30 days after seeding.

The differences observed in Fresh leaf biomass (BFF) and Fresh stem biomass (BFE) are due to the fact that water makes up a large part of the mass of young leaves. Higher amounts of water favor stomatal opening, allowing a better assimilation of $\mathrm{CO}_{2}$ and consequently an increase in leaf production and foliar area. Taiz and Zeiger (2006) state that $90 \%$ of leaf fresh mass is determined by the amount of water delivered during the development cycle of plants, and that this distribution directly influences plant metabolism and nutrient transport within the plant.

The water stress to which the $\mathrm{T} 2$ seedlings were submitted markedly decreased the growth rate of all seedling parts. This result is in agreement with the conclusion of Chaves, Flexas and Pinheiro (2009), who state that one of the main processes affected by water stress is the net assimilation rate of $\mathrm{CO}_{2}$, which reduces the growth and accumulation of dry matter as a result of lower stomatal conductance and plant transpiration.

The decrease in growth of seedlings grown under water stress can be explained by the lower water availability needed for cell expansion. Thus, it could be considered a survival strategy of the plant to reduce the specific surface area exposed to transpiration and as a result, this would distribute a greater portion of photosynthates toward root growth (Taiz \& Zeiger, 2009). $\mathrm{CO}_{2}$ absorption and thus the rate of photosynthesis decreased under water stress conditions, which would have directly affected nitrogen concentration, leaf production and leaf 
blade length. Reference values reported by Pimentel (2012) were used, who described the nutrient content of 6-month-old macaúba seedlings (Table 1).

In a study investigating the impact of water stress on oil palm, Rivera-mendes, Cuenca, and Romero (2016) found that there is a significant reduction in the uptake of some macronutriments, in particular $\mathrm{N}$, and that this is related to the gas exchange since water stress disrupts plant metabolism, causing stomatal closure and thus reduction in the transpiration and photosynthesis rates. This limits the transport of nutrients, particulary nitrogen and ultimately reduces the production of dry matter. It was observed that the difference in $\mathrm{N}$ content in treatments 1 and 2 was smaller between each of these two treatments compared to the difference between each of these two treatments and the control.

When comparing the nutrient content of each treatment with the reference values (Pimentel, 2012), it was observed that the seedlings in treatments $\mathrm{T} 0, \mathrm{~T} 1$ and $\mathrm{T} 2$ experienced deficiencies for $\mathrm{N}, \mathrm{Mg}$ and $\mathrm{S}$. However, the treatment that showed the smallest difference with the reference data was T0. It was observed that the $\mathrm{N}$ content was higher in seedlings with high water availability (T0), indicating that the reduction in the number of irrigations affected the uptake and assimilation of $\mathrm{N}$ by the roots.

The values of $\mathrm{K}$ and $\mathrm{Ca}$ exceeded the optimal values for all treatments. This may be due to the high demand for these nutrients during the seedlings phase, since these nutrients impact stomatal control, which regulates the amount of water inside the stomatal cavities and cellular elongation (Pimentel, 2012). Higher amounts of K and $\mathrm{Ca}$ were found in the seedlings with the lowest irrigation frequency, possibly as a result of lower plant water uptake.

Considering that $\mathrm{P}$ in plants is used as an energy source, it seems plausible that the amount of $\mathrm{P}$ absorbed by the seedlings that received more water (T0) was used for the subsequent absorption and assimilation of $\mathrm{N}$ that later accumulated as dry biomass in the plants. In seedlings grown under water stress, $\mathrm{P}$ was kept in the organs due to a lack of water to transport it. This explains the high concentrations of $\mathrm{P}$ in the leaves that were submitted to water stress, since this decreases the nutrient absorption by the plants because the ions can only be transported from the roots to the stem and shoots by water (Novais, Barros, \& Neves, 1990).

Table 1. Comparison of macro and micronutrients in leaves as reported by Pimentel (2012), and as measured at the end of the treatments reported here

\begin{tabular}{|c|c|c|c|c|}
\hline & Pimentel (2012) & T0 & T1 & T2 \\
\hline & \multicolumn{4}{|c|}{ 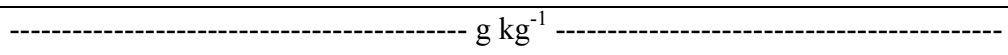 } \\
\hline $\mathbf{N}$ & 32.30 & 23.40 & 17.28 & 17.90 \\
\hline $\mathbf{P}$ & 2.20 & 3.47 & 5.66 & 5.52 \\
\hline $\mathbf{K}$ & 20.40 & 46.56 & 51.91 & 68.02 \\
\hline $\mathbf{C a}$ & 14.90 & 23.31 & 18.97 & 24.11 \\
\hline Mg & 4.40 & 2.27 & 2.40 & 2.77 \\
\hline \multirow[t]{2}{*}{$\mathbf{S}$} & 2.30 & 0.26 & 0.31 & 0.37 \\
\hline & \multicolumn{4}{|c|}{ 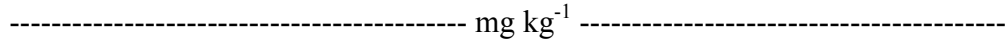 } \\
\hline Mn & 98.00 & 40.97 & 41.14 & 47.28 \\
\hline $\mathbf{C u}$ & 3.00 & 6.98 & 8.67 & 8.77 \\
\hline $\mathbf{F e}$ & 296.00 & 72.54 & 84.15 & 161.31 \\
\hline Zn & 20.00 & 21.75 & 25.12 & 23.49 \\
\hline
\end{tabular}

Note. T0: Treatment zero; T1: Treatment 1; T2: Treatment 2.

Regarding the micronutrients, it was observed that the seedlings of all the treatments experienced deficiency of $\mathrm{Mn}$ and $\mathrm{Fe}$ as well as an excess of $\mathrm{Cu}$ and $\mathrm{Zn}$. The Mn values were similar for all treatments; however, the $\mathrm{Fe}$ deficiency was highest in the T0 treatment. The absorption of $\mathrm{Fe}$ and $\mathrm{Mn}$ is linked to the presence of $\mathrm{P}$ in the plant, which is responsible for the movement of some macronutrients, such as the metals, as have been seen for $\mathrm{T} 2$ : the amount of $\mathrm{Fe}$ and $\mathrm{Mn}$ was directly correlated to the amount of phosphorous present.

The alteration of irrigation in Acrocomia aculeata induces stress that caused changes in its physiology and consequently, its morphology, which makes it possible to obtain plants with desirable characteristics for high future productions. The study of the behavior of this species under conditions of water stress provides insight as 
to the places where it can be produced, because it is a rustic plant. Besides, as it was presented in this work, it allows to adapt well in conditions of water deficit because of the high survival rate.

In addition, these changes provide information on the proper management of the macaúba seelings in pré-nursery conditions and that have a direct impact on the economic values invested in the productions of this crop.

It is necessary to continue the study of the Acrocomia acualeata's capacity for recovery when other environmental factors are altered.

\section{Conclusions}

> Macaúba seedlings grown under water stress showed specific changes in morphological characteristics: reduced aerial parts, stem thickness, and fresh and dry biomass of the leaves.

> The photosynthate accumulation was more efficient in plants under water stress (T2: One irrigation per day, starting at 30 days after seeding), showing a photosynthate distribution more similar to the control treatment (T0: Two irrigations per day for the entire 90-day experimental period).

$>\quad$ Increased content of $\mathrm{K}, \mathrm{Ca}, \mathrm{S}$ and $\mathrm{Fe}$ in the aerial parts was observed at the lowest irrigation frequency (T2). Reduced $\mathrm{P}$ content in the aerial plant parts was observed in the seedlings that were irrigated two times per day (T0).

\section{Acknowledgements}

To the Federal University of Viçosa, for the technical-financial support and CAPES for the assignment of a doctorate scholarship.

To the company Acrotech Sementes e Reflorestamento, for the financial support in the purchase of equipment, the concession of the experimental area and the macaúba seeds.

\section{References}

Azevedo Filho, J. A., Colombo, C. A., \& Berton, L. H. C. (2012). Macaúba: Palmeira nativa como opção bioenergética. Pesquisa \& Tecnologia, 9(2). Retrieved from http://www.aptaregional.sp.gov.br/index.php? option=com_docman\&task $=$ doc_view\&gid=1275\&Itemid=284

Barleto, E. A. (2011). Respostas Ecofisiológicas de Acrocomia aculeata (Jacquin) Loddies ex Martius ao déficit hídrico sazonal e à disponibilidade de nutrientes. Universidade de Brasilia.

Berton, L. H. C. (2013). Avaliação de Populações Naturais, estimativas de parametros genéticos e seleção de genótipos elite de Macaúba (Acrocomia aculeata). Instituto Agronômico.

Chaves, M. M., Flexas, J., \& Pinheiro, C. (2009). Photosynthesis under drought and salt stress: Regulation mechanisms from whole plant to cell. Annals of Botany, 103, 551-560. https://doi.org/10.1093/aob/mcn 125

Colombo, C. A., Berton, L. H. C., Diaz, B. G., \& Ferrari, R. A. (2017). The oil \& protein crop supply chain in south america la filière oléoprotéagineuse en amérique du sud. OCL, 25(1), D108. https://doi.org/ $10.1051 / \mathrm{ocl} / 2017038$

dos Reis, E. F., Pinto, J. F. N., da Assunção, H. F., \& da Silva, D. F. P. (2017). Genetic diversity of macaúba fruits from 35 municipalities of the state of Goiás, Brazil. Pesquisa Agropecuaria Brasileira, 52(4), 277-282. https://doi.org/10.1590/S0100-204X2017000400008

Evaristo, A. B., Martino, D. C., Ferrarez, A. H., Donato, D. B., Carneiro, A. de C. O., \& Grossi, J. A. S. (2016). Potencial energético dos resíduos do fruto da macaúba e sua utilização na produção de carvão vegetal. Ciencia Florestal, 26(2), 571-577. https://doi.org/10.5902/1980509822757

Fisher, R. A. (1935). The Design of Experiments. Hafner Publishing Company.

Giraldo Montoya, S., Motoike, S. Y., Kuki, K. N., De Oliveira, C. M., \& Gomes Honorio, I. C. (2015). Registro da presença e danos causados por coleopteros em macaúba. Pesquisa Florestal Brasileira, 35(82), 159. https://doi.org/10.4336/2015.pfb.35.82.763

Hiane, P. A., Baldasso, P. A., Marangoni, S., \& Macedo, M. L. R. (2006). Chemical and Nutritional Evaluation of Kernels of Bocaiuva Acrocomia aculeata (Jacq.) Lood. Ciênc. Tecnol. Aliment., Campinas, 26(3), 683-689. https://doi.org/10.1590/S0101-20612006000300031

Martins, R. F. (2011). Diferentes ambientes protegidos e substratos para a formação de mudas bocaiúva, a partir de sementes pré-germinadas. Universidade Estadual de Mato Grosso do Sul, Mato Grosso do Sul.

Motoike, S. Y., Carvalho, M., Pimentel, L. D., Kuki, K. N., Paes, J. M. V., Dias, H. C. T., \& Sato, A. Y. (2013). A 
cultura da macaúba: Implantação e manejo de cultivos racionais. Viçosa: Editora UFV.

Novais, R. F., Barros, N. F. de, \& Neves, J. C. L. (1990). Nutrição mineral do eucalipto. Relação solo-eucalipto (Vol. 1, pp. 25-91). Viçosa, MG: Folha de Viçosa.

Pimentel, L. (2012). Nutrição Mineral Da Macaúba: Bases Para Adubação E Cultivo. Universidade Federal de Viçosa, Viçosa.

Pimentel, L. D., Bruckner, C. H., Martinez, H. E. P., Motoike, S. Y., Manfio, C. E., \& Santos, R. C. dos. (2015). Effect of Nitrogen and Potassium Rates on Early Development of Macaw Palm. Revista Brasileira de Ciência Do Solo, 39(6), 1671-1680. https://doi.org/10.1590/01000683rbcs20140352

Rivera-mendes, Y. D., Cuenca, J. C., \& Romero, H. M. (2016). Physiological responses of oil palm (Elaeis guineensis Jacq.) seedlings under different water soil conditions. Agronomía Colombiana, 34(2), 163-171. https://doi.org/10.15446/agron.colomb.v34n2.55568

Sanjinez-Argandoña, E. J., \& Chuba, C. A. M. (2011). Biometrical, physical and chemical characterization of bocaiuva (Acrocomia aculeata (Jacq.) lodd. Revista Brasileira de Fruticultura, 33(3), 1023-1028. https://doi.org/10.1590/S0100-29452011000300040

Santos, A. C. R. dos, Azevedo, R. A. de, Virginio Júnior, G. F., Rodriguez, N. M., Duarte, E. R., Geraseev, L. C., ... Geraseev, L. C. (2017). Effects of macauba cake on profile of rumen protozoa of lambs. Revista Brasileira de Zootecnia, 46(3), 251-256. https://doi.org/10.1590/s1806-92902017000300010

Sharp, R. E. (2002). Interaction with ethylene: Changing views on the role of abscisic acid in root and shoot growth responses to water stress. Plant, Cell and Environment, 25, 211-222. https://doi.org/10.1046/ j.1365-3040.2002.00798.x

Siqueira, P. B. (2012). Caracterização Bioquímica e Compostos Bioativos de Macaúba (Acrocomia aculeata (Jacq.) Lodd. ex Mart.). UNICAMP.

Taiz, L., \& Zeiger, E. (2006). FisiologiaVegetal (3rd ed.). Sinauer Associates, Inc.

Taiz, L., \& Zeiger, E. (2009). Fisiologia Vegetal (4th ed.). Artmed.

Tukey, W. J. (1953). The Problem of Multiple Comparisons. Multiple Comparisons. Chapman \& Hall. Retrieved from http://ci.nii.ac.jp/naid/10030867280/en

\section{Copyrights}

Copyright for this article is retained by the author(s), with first publication rights granted to the journal.

This is an open-access article distributed under the terms and conditions of the Creative Commons Attribution license (http://creativecommons.org/licenses/by/4.0/). 